\title{
KONSELING PANCAWASKITA UNTUK MENINGKATKAN KETERAMPILAN PRAKSIS KONSELING PADA GURU BK SMP NEGERI 35 BANJARMASIN
}

\author{
${ }^{1}$ Ainun Heiriyah, ${ }^{2}$ Sri Ayatina Hayati, ${ }^{3}$ Farial, ${ }^{4}$ Mahfuz \\ ${ }^{1}$ Dosen Prodi Bimbingan dan Konseling, FKIP, UNISKA MAB, Indonesia \\ ${ }^{2}$ Dosen Prodi Bimbingan dan Konseling, FKIP, UNISKA MAB, Indonesia \\ ${ }^{3}$ Dosen Prodi Bimbingan dan Konseling, FKIP, UNISKA MAB, Indonesia \\ ${ }^{4}$ Dosen Prodi Bimbingan dan Konseling, FKIP, UNISKA MAB, Indonesia \\ Email: ainunheiriyah@gmai.com, hayati.sriayatina@gmail.com, varialuniska@gmail.com, \\ mahfuzuniska@gmail.com
}

\begin{abstract}
ABSTRAK
Gambaran pengetahuan guru BK SMP Negeri 35 Banjarmasin menunjukkan kategori rendah dengan total skor rata-rata 9 hal ini menunjukan pemberian kegiatan ini sangat diperlukan. Sedangkan, gambaran keterampilan guru BK SMP Negeri 35 Banjarmasin menunjukkan kategori tinggi dengan total skor rata-rata 32,5 hal ini menunjukkan peningkatan keterampilan guru BK bertambah signifikan terhadap pendekatan konseling pancawaskita. Hal tersebut kiranya wajar, karena guru BK SMP Negeri 35 Banjarmasin telah diberikan mengenai materi dan pelatihan "pendekatan konseling pancawakita".
\end{abstract}

Kata Kunci: Konseling Pancawaskita, Keterampilan Praksis Konseling

\begin{abstract}
The description of the knowledge of the BK teacher of SMP Negeri 35 Banjarmasin shows a low category with an average total score of 9 , this shows the provision of this service is very necessary. Meanwhile, the description of BK teacher skills at SMP Negeri 35 Banjarmasin shows a high category with an average total score of 32.5. This shows that the increase in BK teacher skills increased significantly to the Pancawaskita counseling approach. This seems reasonable, because the teacher of BK Negeri 35 Banjarmasin Middle School has been given about the material and training "Pancawakita counseling approach".
\end{abstract}

Keywords: Pancawaskita Counseling, Praxis Counseling Skills 


\section{PENDAHULUAN}

Layanan bimbingan dan konseling perlu diaplikasikan di sekolah, mengingat kondisi situasi global yang membuat kehidupan semakin kompetitif dan membuka peluang bagi manusia untuk mencapai status dan tingkat kehidupan yang lebih baik. Dampak positif dari kondisi global yang telah mendorong manusia untuk terus berpikir, meningkatkan kemampuan, dan tidak puas terhadap apa yang dicapai saat ini. Adapun dampak negatif dari globalisasi tersebut adalah (1) keresahan hidup dikalangan masyarat yang semakin meningkat karena banyaknya konflik, stres, kecemasan, dan frustasi; (2) adanya kecendrungan pelanggaran pelanggaran disiplin, kolusi dan koropsi, makin sulit diterapkannya ukuran baik-jahat serta benar-salah secara lugas; (3) adanya ambisi kelompok yang telah menimbulkan konflik, tidak saja konflik psikis, tetapi juga konflik fisik, seperti penggunaan obat-obat terlarang.

Untuk mengatasi masalah tersebut perlu disiapkan insan dan sumber daya manusia Indonesia yang bermutu. Manusia Indonesia yang bermutu, yaitu manusia yang harmonis lahir dan batin, sehat jasmani dan rohani, bermoral, menguasai ilmu pengetahuan dan teknologi secara professional, serta dinamis dan kreatif.
Pelayanan konseling adalah suatu bentuk bantuan yang melibatkan kemampuan profesional (guru BK). Guru BK Profesional adalah guru BK yang menguasai keterampilan dasar pendekatan dan teknik konseling. Setidaknya guru BK harus menguasai satu atau lebih keterampilan konseling dari pendekatan dan teori konseling yang ada.

Guru BK lemah dalam menggunakan pendekatan konseling pancawaskita. Hal ini terjadi di salah satu SMP di kota banjarmasin, terutama pada sekolah SMP Negeri 35 Banjarmasin. Proses konseling yang terjadi tidak diwarnai dengan berbagai pendekatan konseling, sehingga proses konseling tidak ada ciri khas tersendiri terhadap pendekatan-pendekatan yang digunakan dalam proses konseling yang konkrit. Hasilnya konseling yang terjadi tidak begitu efektif dan tak berwarna.

\section{METODE}

Metode yang digunakan dalam pelaksanaan menggunakan metode ceramah, pelatihan terstruktur, dan evaluasi.

\section{HASIL DAN PEMBAHASAN}

Hasil dari instrument tersebut telah dianalasis dan dirangkum serta disajikan dalam berbagai data yang dapat dilihat di bawah ini sebagai berikut:

Tabel 1.1 Kategori Interval

\begin{tabular}{lr}
\hline Interval & Kategori \\
\hline 30 ke atas & Tinggi \\
$20-30$ & Sedang \\
20 ke bawah & Rendah \\
\hline
\end{tabular}

Sumber: Data diolah tahun 2020 
Tabel 1.2 Skor Rata-Rata Tingkat Pengetahuan Peserta

\begin{tabular}{lr}
\hline Aspek & $\begin{array}{c}\text { Skor } \\
\text { Rata-rata }\end{array}$ \\
\hline Pengetahuan mengenai pendekatan konseling & 4,5 \\
pancawaskita & 5 \\
Pemahaman mengenai tahapan konseling Pancawakita & $\mathbf{9 , 5}$ \\
\hline Total Skor & Rendah \\
Kategori
\end{tabular}

Sumber: Data diolah tahun 2020

Khusus untuk artikel konseptual, cukup berisi pembahasan saja. Pemaparan tentang hasil tidak perlu dilakukan. Dengan demikian, untuk artikel konseptual, judul hanya bertuliskan 'Pembahasan'. Penulis dapat menyertakan gambar, grafik, atau diagram dalam pembahasan (juga bisa di bagian pendahuluan atau metode sesuai dengan kebutuhan penulis). Gambar 1 akan memberikan contoh penggunaan gambar dalam. Jurnal Consulenza:Bimbingan Konseling dan Psikologi

Tabel 1.2 Skor Rata-Rata Keterampilan Peserta

\begin{tabular}{lr}
\hline Aspek & $\begin{array}{r}\text { Skor } \\
\text { Rata-rata }\end{array}$ \\
\hline Kepasihan dalam penggunaan tahapan kons. pancawaskita & 9,5 \\
\hline Kecocokan atau keserasian saat menggunakan konseling & 8,5 \\
Pancawaskita & 7,5 \\
\hline Memberikan Layanan dengan memadukan pendekatan & 7 \\
Konseling Pancawaskita & \\
Melakukan Konseling individual dan memilih konseling & $\mathbf{3 2 , 5}$ \\
Pancawaskita Sebagai teknik penyelesaian masalah & Tinggi \\
\hline Total Skor & \\
Kategori
\end{tabular}

Sumber: data diolah tahun 2020

Dari tabel 4.2 di atas terlihat gambaran keterampilan guru BK SMP Ne1geri 35 Banjarmasin menunjukkan kategori tinggi dengan total skor rata-rata 32,5 . Hal ini menunjukkan peningkatan keterampilan guru BK SMP Negeri 35 Banjarmasin bertambah signifikan terhadap pendekatan konseling pancawaskita.

\section{SIMPULAN}

Kegiatan ini bertujuan untuk memberikan pengetahuan baru mengenai pendekatan konseling pancawaskita dan guru BK SMP Negeri 35 Banjarmasin mampu berpraktik dengan handal dan terampil dalam melakukan proses konseling individual dengan mengunakan "pendekatan konseling pancawaskita". 


\section{DAFTAR PUSTAKA}

Arintoko. 2011. Wawancara Konseling di Sekolah Lengkap dengan Contoh Kasus dan Penanganan. Yogyakarta. C.V Andi Offset.

Prayitno, 1998. Konseling Pancawaskita. Padang. Pendidikan IKIP Padang.
Sutirna. 2010. Bimbingan dan Konseling Pendidikan formal, Non Formal, dan Informal. Yogyakarta. Andi Offset.

Willis, Sofyan S. 2009. Konseling Individual, Teori dan Praktek. Bandung. Alfabeta, CV. 